\title{
Darfur and the genocide debate
}

\author{
Simon Ben Okolo ${ }^{\star}$
}

\section{Abstract}

The atrocities committed by the Government of Sudan backed Janjaweed militia in the ongoing conflict in Darfur have been labelled differently by analysts and scholars. While some argue that the crimes fall under the so-called crime of crimes - genocide, others are of the opinion that the crimes do not qualify as genocide. While the international community is playing a 'labelling' game with the situation in Darfur, civilians continue to die. What should interest the civilians more is that the international community offers them the protection as articulated under the different international conventions.

* Simon Ben Okolo holds an LL.B., B.L. (Calabar, Nigeria), LL.M. and M.A. (University of Witwatersrand). He just submitted his Ph.D. thesis at the Department of International Relations, University of Witwatersrand. This article is culled from the thesis. 


\section{Simon Ben Okolo}

\section{Introduction}

The conflict in Darfur is in its $5^{\text {th }}$ year with no signs of abating. This, despite much international attention received both from international law and international relations scholars. While the media are more interested in sensationalising the conflict, scholars are interested in determining the category of crimes if any, that the atrocities fit in. Although opinions seem to differ as to the correct categorisation of the crimes and those responsible, there seems to be a consensus that the atrocities constitute, at the minimum, serious violations of international human rights law and international humanitarian law. ${ }^{1}$ This paper attempts to look at the Darfur situation through the lens of genocide. The legal framework on the crime of genocide sets the stage for the analysis; and the definitions provided by the Genocide Convention (Convention on the Prevention and Punishment of the Crime of Genocide 1948) and the International Criminal Court Statute (Rome Statute) (1998) are used as the standard. According to these definitions, the paper argues that the atrocities as witnessed in Darfur constitute genocide despite the international community's reluctance in acknowledging it. The responsibility of the international community to the civilian population of Darfur is discussed and the fact that states should prevent and punish acts of genocide is underscored. The paper conversely argues that even if the crimes do not amount to genocide, they are still of a nature that should trigger the responsibility to protect mechanism. In conclusion, the paper asserts that the legal gymnastics of labelling the crimes are of no use to the civilians caught up in violent conflicts. They are more interested in getting protection from the international community.

\section{The legal and normative framework of the crime of genocide}

The atrocities committed both by the government of Sudan and the Janjaweed militia in Darfur have led to many international law and international relations

1 For a detailed and in-depth account of the atrocities committed by the Janjaweed, see Flint and De Waal 2005; Prunier 2005; United Nations High Commissioner for Human Rights 2006; and Lefkow 2004. 
experts debating whether they fall under the category of the so-called crime of crimes - genocide. Notwithstanding the political nature of the debate, it must be observed that in order for the crime of genocide to be established, the international community needs to approach the evidence with open minds and without preconceived notions. However, whether the crimes are of the magnitude to qualify as genocide is a moot issue to the civilians who are constantly in fear for their lives.

The crime of genocide under international law is relatively modern. This is because it was only in 1948 that the world recognised such a crime. Of course, this is not to state that acts which could have been described as genocide never happened earlier than 1948. For instance, the massacre of the Armenians by the Turkish state in 1915 has been described as genocide (Chorbaijan 1999:xv). The institutionalised origin of the law on genocide can be traced to the atrocities of the Nazis during World War II and the subsequent Nuremberg trials. However, during the trials of the war criminals at Nuremberg, there was no charge of genocide against the Nazis due to the non-existence of the crime of genocide in international law then. They were instead charged for crimes against peace and crimes against humanity (Van der Vyver 1999:286). ${ }^{2}$ However, there were references to genocide during the trial. It was only in 1946 that the General Assembly through a Resolution proclaimed the existence of the crime of genocide. ${ }^{3}$ With the adoption of the Genocide Convention in 1948 and the recognition that the crime has the status of jus cogens (compelling law), the crime of genocide became a subject of universal jurisdiction (Van der Vyver 1999:287). While genocide is always organised, planned, promoted and executed by those in authority, it usually requires the support of the general public to succeed (Spangeburg and Moser 2000:39). However, when the government in question is an authoritarian regime as in the case of Darfur, Sudan, the support of the general public need not be necessary for genocide to succeed. Genocide normally occurs under the façade of war or colonial conquest and so long as the state or the perpetrators come out victorious, the question of domestic prosecution is never contemplated (Schabas 2000:1). The prohibition of genocide

2 See also International Military Tribunal, Nuremberg 1946:27-92.

3 International Military Tribunal, Nuremberg 1946:27-92. See G.A. Res. 96(1) 1947. 


\section{Simon Ben Okolo}

is equal to the provision of the right to life in the international human rights instruments. While the instruments concern themselves with the individual's life, the Genocide Convention is concerned with the right to human existence of a group (Schabas 2000:6). ${ }^{4}$ The Genocide Convention defines genocide as:

any of the following acts committed with intent to destroy, in whole or in part, a national, ethnic, racial, or religious group, as such:

a. Killing members of the group;

b. Causing serious bodily or mental harm to members of the group;

c. Deliberately inflicting on the group conditions of life calculated to bring about its physical destruction in whole or in part;

d. Imposing measures intended to prevent births within the group;

e. Forcibly transferring children of the group to another group (Convention on the Prevention and Punishment of the Crime of Genocide 1948: art. II). 5

The International Criminal Court (ICC) Statute (1998) gives the court the jurisdiction to punish perpetrators of genocide, crimes against humanity, and war crimes in situations where the domestic courts of a country with custody of the suspects are 'unwilling' or 'unable' to do so. 6 This is what is echoed by the principle of responsibility to protect. There is, therefore, a two-prong approach to the protection of civilians - political and legal. That means that in a situation where the international community fails to exercise its responsibility to protect the civilians and genocide occurs, the international judicial system would have to step in. It must be noted however that the ICC does not bring within its purview conspiracy to commit genocide, direct and public incitement to commit genocide, attempt to commit genocide, or complicity in genocide.

4 See G.A. Res. 96(1) 1947 which declares that 'genocide is a denial of the right of existence of entire human groups, as homicide is the denial of the right to live of individual human beings'.

5 See also International Criminal Court Statute 1998: art. 6.

6 See International Criminal Court Statute 1998: art. 5 and 17. 
The question this therefore raises, especially in the context of the conflict in Darfur, is to what extent the ICC would be able to prosecute those who were part of the planning of the atrocities in Darfur. This question is apposite, especially against the backdrop of the level of atrocities in Darfur. While the definition of genocide does not bring within its purview the policy elements articulated in the definition of crimes against humanity, it is reasonable to assume that the atrocities in Darfur that have been traced to the Janjaweed could not have been possible without the official support of Khartoum. It would, therefore, amount to double killing for the victims if those who were complicit in the crime are left to escape justice because of the above provision. In deciding if the largescale killings in Darfur constitute genocide, the number of victims is definitely not a key factor. However, the number of victims plays its important role in determining the level of the targeted population that has suffered and also it acts as an appeal to world opinion (Prunier 2005:148). With the international media putting the deaths resulting from the conflict at about 300000 , it must be stated that even if the number of victims were relevant to prove a case of genocide, the number should qualify.

It has often been stated that the rebel groups might equally be complicit in the atrocities in the Darfur region, but even if this could be proved, it cannot constitute acts of genocide. Mass killings of the members of the perpetrator's own group should not be confused with genocide, as it is inconsistent with the purposes of the Convention which is aimed at protecting national minorities from ethnic hatred-based crimes. Such mass killings should instead be viewed as constituting crimes against humanity (Schabas 2000:119-20). The initial phrase of the definition of genocide in the Convention sets out the mens rea (guilty mind) or mental element of the crime that must be established alongside the actus reus (culpable act) before a conviction can be sustained in the court (Schabas 2000:151). The mental element is the 'intent to destroy, in whole or in part, a national, ethnic, racial, or religious group, as such.' The actus reus of the offence of genocide is contained in the second leg of the definition. It specifies an exhaustive list of acts which constitute the crime (Schabas 2000:154). ${ }^{7}$

7 See definition of genocide in Convention on the prevention and punishment of the crime of genocide 1948 . 


\section{Simon Ben Okolo}

Intent is a critical element in determining whether a particular set of circumstances amounts to genocide. Unless this intent to destroy the group in whole or in part is expressed, it would be difficult, if not impossible, to prove such intent. In a situation where a large number of the group was killed, however, intent might be inferred (Bryant 1975:686). For instance, in Prosecutor $v$ Kayishema and Ruzindana, the International Criminal Tribunal for the former Yugoslavia (ICTY) clarified that the intent to destroy a group 'in part' entails the destruction of a 'considerable number of individuals' (ICTY 1999a: para 97). However, in Prosecutor $v$ Jelisi, the ICTY trial chamber interpreted it to be a destruction of 'a substantial part' (ICTY 1999b: para 82). While genocide is regarded as a very serious crime, crimes against humanity are equally as grave. The Appeal Chamber in Prosecutor $v$ Kayishema and Ruzindana was of the view that genocide is not the crime of crimes (ICTY 2001b). It held that there was no hierarchy of crimes under the International Criminal Tribunal for Rwanda (ICTR) Statute and that all the crimes specified therein are 'serious violations of international humanitarian law', capable of attracting the same sentence. Despite the non-hierarchical nature of crimes under the ICTR Statute, it can be argued that since the nature of proof required for a conviction of genocide is more stringent than that required for crimes against humanity and other crimes under the statute, a higher value is placed on the crime of genocide. Moreover, the fact that genocide is an act intended to destroy a protected group makes it more serious.

It is instructive to note that the first time the United Nations (UN) Security Council referred to the word genocide was in its Resolution 925 of 8 June 1994 with respect to the atrocities in Rwanda - this coming 46 years after the entering into force of the Genocide Convention and after a lot of vacillation by the Security Council. Scholarly debate exists on whether the crime of genocide attracts universal jurisdiction. In customary international law, offences that attract universal jurisdiction for their prosecution are piracy, slave trade, and trafficking in women and children. This is based on the notion that these offences are committed in 'no man's land', where no state has jurisdiction. However, multilateral treaties have accorded universal jurisdiction to some other classes of crimes in international law, like: torture, attack on diplomats and others 
(Schabas 2000:354). ${ }^{8}$ Notwithstanding the nature of the crime of genocide, the question of it acquiring the un-envious status of universal jurisdiction is still very contentious as can be gleaned from the proceedings and argument at the conference on the Rome Statute before the conference compromised by recognising only territorial and active personal jurisdiction. Schabas is however of the view that the UN human rights instruments favour the existence of a universal jurisdiction in the case of genocide (Schabas 2000:362). ${ }^{9}$ The practice of universal jurisdiction by states in cases of alleged genocide is not uniform. While some states accept it, others do not. ${ }^{10}$ Notwithstanding the non-express provision for the imposition of the legal duty of aut dedere aut judicare - try or extradite - as is provided by the Geneva Conventions in respect to grave breaches, by implication, the Genocide Convention imposes such obligation especially when Articles I, IV, V, VI, and VII are read together (Schabas 2000:404). It is usually difficult for the state where the genocide took place to prosecute the perpetrators, especially where the regime is still in power or if they still exert influence over the political system in the state (Schabas 2000:354).

\section{Contextualising the Darfur Situation}

While the world is right in remembering the 800000 that lost their lives during the 1994 Rwanda genocide, a befitting memorial for the victims would also be that the world does not allow such fate to befall others. However, barely ten years after the genocide, a fate as gruesome as what befell them is being visited

8 See Convention Against Torture and Other Cruel, Inhuman or Degrading Treatment or Punishment 1987 and Convention on the Prevention and Punishment of Crimes Against Internationally Protected Persons Including Diplomatic Agents 1977.

9 See also ICTR 1999, the decision on the Prosecutor's Motion to Withdraw the Indictment, 18 March 1999, where the ICTR recognises the existence of universal jurisdiction for the crime of genocide. The trial of two Rwandan Nuns by the Belgian court for the 1994 Rwandan genocide was also hinged on the Universal Jurisdiction paradigm as it applies to the crime of genocide.

10 Germany, Denmark, Austria, Switzerland and Belgium, for instance, accept universal jurisdiction for genocide, while the United States of America does not. The trial of the two Rwandan Nuns for genocide by the Belgian court was premised on the existence of a universal jurisdiction for the crime of genocide. 


\section{Simon Ben Okolo}

on the Darfurians (Agbakwa 2005:531). As stated earlier, the Darfur conflict has attracted varied analysis as to whether the atrocities amount to genocide or not. While states are very reluctant to use the 'G' word due to its implied obligation on the international community to act, the United States of America was bold to state that the atrocities amounted to genocide. It is usually suggested that genocide is the ultimate crime against humanity. ${ }^{11}$ This is mainly because the crime of genocide has the capability of destroying all or part of the targeted or protected group, unlike in crimes against humanity where the perpetrator need not have such intention (ICTY 2001a: para 182). The underlying genocidal offences must have the potential, even if remote, to contribute to the complete or partial destruction of the victims' group. Unlike crimes against humanity, the crime of genocide need not be widespread or a systematic attack against a civilian population. It could be planned or committed on a large scale or as an individual undertaking (ICTY 1999b: para 98). While crimes against humanity can be committed against any individual, genocide can only be committed against individuals who belong to the protected groups categorised by their national, ethnic, racial, or religious identity (ICTY 2001d: para 682). ${ }^{12}$ In the case of Darfur for instance, the group can be identified by their belonging to the same ethnic and racial group of black Africans.

In order to sustain a conviction for genocide, it must be proved that the underlying acts were directed with the intention of destroying, in whole or in part, one of the protected groups. With the evidence available, it could be argued that the acts by the government of Sudan and its Janjaweed militia were directed at the destruction of the black African group in Darfur, although the destruction so far achieved has been partial. It is therefore a matter of conjecture what the level of destruction would have been if the international community did not raise alarm over the atrocities in Darfur. However, if we were to infer from the continued attack of the group by the government and its allied Janjaweed militia, it would become obvious that the government wants to wholly destroy the group. Ali Nafi Ali, a presidential assistant to President Omar Hassan al Bashir,

11 See G.A. Res.2391 1968.

12 The tribunal held that the protected 'group' under the genocide definition differs essentially from a 'population' for the purpose of crimes against humanity. 
is reported as saying: '[W]e have no problem fighting those who fight us. The UN Security Council will not stop us even if the whole world screams' (Sudan Tribune 2008). Granted that proving intention is very difficult, it can be inferred 'by showing a pattern of purposeful action' (Fein 1994:97).

The issue that should occupy our minds as to the atrocities in Darfur is not the question under which label of atrocious crime we should group it, but the need for a total condemnation of the acts, followed by the international community's efforts at putting a stop to such atrocities, both at Darfur and elsewhere in the world. Prunier (2005:156) captures the cynicism of the international community's love for labelling when he stated: '[I]t is in fact a measure of the jaded cynicism of our times that we seem to think that the killing of 250,000 people in a genocide is more serious a greater tragedy than that of 250,000 people in non-genocidal massacres.' While this might be true, one should not lose sight of the implication of genocidal attacks. This is an attack targeted at our hypothetical 250000 who have something in common intended to destroy it in whole or in part. The other 250000 could have been randomly assembled. A case in point is the people that died in the 9/11 (2001) attack on the World Trade Centre. Of course, international criminal law provides that for such a situation where the attack is widespread and systematic and leads to many deaths, the perpetrators can be charged for crimes against humanity. Crimes against humanity by itself are heinous crimes. However, it does not attract the same moral opprobrium and legal obligation as genocide does. The Appeal Chamber in Prosecutor $v$ Krsti captured succinctly the grievous nature of the crime of genocide when it stated:

[A] mong the grievous crimes this Tribunal has the duty to punish, the crime of genocide is singled out for special condemnation and opprobrium. The crime is horrific in its scope; its perpetrators identify entire human groups for extinction. Those who devise and implement genocide seek to deprive humanity of the manifold richness its nationalities, races, ethnicities and religions provide. This is a crime against all humankind, its harm felt not only by the group targeted for destruction, but by all of humanity (ICTY 2003: para 36). 


\section{Simon Ben Okolo}

However, Fein cautions that the term 'genocide' should not be used loosely so as not to lose its meaning. According to her, people use it to 'vent outrage and to describe a perceived threat to themselves' (Fein 1994:95). The use of the word 'genocide' by victims of perceived massive violations of human rights and other atrocities to call world attention to their situation shows the level of opprobrium attached to the crime of genocide, not just in international law, but also in the court of public opinion. It must be acknowledged, however, that genocide never occurs as a result of accident. It is always a premeditated action by the architects of the crime calculated to achieve the ends of the perpetrators (Smith 1994:4). That notwithstanding, sometimes the genocidal consequences of an act might precede the decision to destroy in whole or in part the targeted group. It is, therefore, the continued persistence of the attempt to destroy the group that forms the intention to destroy the group (Smith 1994:4). In the case of Darfur, one may argue that while the state could not have set out initially with the intention of destroying, in whole or in part, the black African group of Darfur, this intention could have developed as the conflict continued. This argument is given credence by the nature of the continued attacks directed against the black African group over a sustained period of five years. Smith (1994:10) argues that the crime of genocide which is only acknowledged in the $20^{\text {th }}$ century has been an ancient phenomenon, and that the perpetrators of genocide in ancient times were never ashamed of it. However, since the $20^{\text {th }}$ century, no country has acknowledged its involvement in the crime.

An argument by Irving Horowitz, that the survival of a people from total annihilation does not qualify such an act as genocide, notwithstanding the means and number of deaths, seems to obscure the understanding of the definition ascribed to genocide. His argument was within the context of the survival of the Igbo of south-eastern Nigeria despite the estimated loss of about 3 million during the Nigerian civil war (Horowitz 1994:25). A cursory look at the definition of genocide as contained in the different international legal instruments reveals that the 'annihilation' need not be total. It is enough if it intends to 'destroy in whole or in part.... If that were not so, why then do we refer to the Jewish holocaust and the Rwanda genocide as genocide, despite the fact that some of them survived? 
In considering whether the crimes in Darfur amount to genocide, the following issues need to be considered. First, do the acts themselves fall within the acts as articulated by the Genocide Convention and the ICC Statute? From the preponderance of evidence available, one can argue that the acts as outlined by the two international conventions mentioned above are in existence, especially the acts of killing members of the group, causing serious bodily or mental harm to the members of the group and deliberately inflicting on the group conditions of life calculated to bring about its physical destruction in whole or in part. ${ }^{13}$ It could also be argued that the act of rape by the Janjaweed is aimed at imposing measures intended to prevent births within the black African group. ${ }^{14}$ This is especially the case when viewed against the backdrop of the Arab culture of ascending miscegenation. ${ }^{15}$ Moreover, all the underlying acts need not be committed by the perpetrator for it to amount to genocide. One of the enumerated acts would be enough to sustain a conviction for genocide if the other aspects of the definition are proved.

The second consideration in the determination of genocide in Darfur would be whether the targeted groups are part of the protected groups under the relevant international conventions. Recourse to Article II of the Genocide Convention and Article VI of the Rome Statute reveals that the black Africans of Darfur qualify as an 'ethnical or racial' group. Evidence suggests that the black Africans in Darfur see themselves as ethnically and racially different from the Arabs. Their culture and language are also different from those of the Arabs. They would, therefore, qualify as an ethnic or racial group. There is evidence to suggest that the people targeted by the government of Sudan and its Janjaweed militia are easily identified as either belonging to the Masaalit, Zaghawa, and Fur ethnic groups or are identified as black Africans (Yusuf 2007). Their black 'Africanness' is what identifies them and sets them aside for such attacks.

13 Some of the surviving victims interviewed by this author recounted how the Sudanese Armed Forces deliberately targeted their villages through aerial bombardment and the Janjaweed looted, pillaged and burnt the villages.

14 Some of the female victims of the Darfur conflict interviewed by this author alleged that they were raped either by the Janjaweed or by members of the Sudan Armed Forces.

15 The Arab lineage system of ascending miscegenation entails that any child born to a non-Arab mother and Arab father becomes Arab. 


\section{Simon Ben Okolo}

The third consideration will be to determine if there was a genocidal intent in the commission of the enumerated crimes. The determination of human intent is not easily discernible, more so, the determination of the intent of a state. ${ }^{16}$ However, in determining intent, inferences can be made from utterances of government officials, especially those who occupy sensitive positions. For instance, Musa Hilal's statement to the intelligence and security chiefs in 2004 to 'change the demography of Darfur and empty it of African tribes' (Flint and De Waal 2005:39) is an indication of what the Janjaweed plans were. Since Musa Hilal has been known not to deny his Janjaweed connection, and since its link with the government has been established, one can, therefore, safely attribute that intention to the government of Sudan. Furthermore, President Al Bashir's statement that 'our priority from now on is to eliminate the rebellion, and any outlaw element is our target... We will use the army, the police, the Mujahedeen, the horsemen to get rid of the rebellion' (Associated Press 2003), is indicative of the government's intention to employ all extra-judicial means in the elimination of the rebellion. The actions of the government during the conflict would also be able to point to what its intentions are. For instance, it could be argued that the indiscriminate bombing of African villages by the government army and the raiding, raping and burning of the villages by the government backed Janjaweed is an indication of the government's intention to destroy in whole or in part the African people of Darfur. The encouragement by the government to the Arab people of Darfur to take over the villages abandoned by the Africans during their flight for safety seems to suggest the overall intention of the government forceful displacement of the black African race (Yusuf 2007). The government's intention could also be inferred from its failure to act to curb the atrocities committed by the Janjaweed and the Sudanese military.

16 See ICTY 2001c, where the Appeals Chamber noted that 'as to proof of specific intent, it may, in the absence of direct explicit evidence, be inferred from a number of facts and circumstances, such as the general context, the perpetration of other culpable acts systematically directed against the same group, the scale of atrocities committed, the systematic targeting of victims on account of their membership of a particular group, or the repetition of destructive and discriminatory acts.' Also, as Lord Denning, an English Lord Justice, stated: Even the devil does not know man's intention. 
The report of the International Commission of Inquiry on Darfur to the United Nations Secretary-General in 2004 is instructive in this paper. The commission, which was chaired by Antonio Cassese visited and consulted extensively in Sudan and Darfur in particular. The commission's view is that genocide did not occur in Darfur, though it argues that two elements of genocide might be deduced from the gross violations of human rights and violations of international humanitarian law perpetrated by the government of Sudan and its Janjaweed militia. These elements are, the actus reus, i.e. 'the killing or causing serious bodily harm or mental harm, or deliberately inflicting conditions of life likely to bring about physical destruction; and second, on the basis of subjective standard, the existence of a protected group being targeted by the authors of criminal conduct' (Report of the International Commission of Inquiry on Darfur to the United Nations Secretary-General 2004). Notwithstanding the presence of the above elements, the very crucial element of genocidal intent appears not to have been present according to the Commission. While the findings of the Commission were relevant to the available evidence in 2004, it must be stated that if the then existing circumstances are re-examined presently, it might be possible to infer the existence of genocidal intent. Be that as it may, it is a matter for the courts to decide - that is if the matter ever gets to be adjudicated upon by the International Criminal Court (ICC).

If however the government of Sudan denies its culpability in genocide, that is, having had a direct hand in the attacks that could be interpreted as genocide; they could still be held liable for failure to act in putting a stop to the atrocities. The principle of responsibility to protect civilians places on the government the onus of showing that it did try to the best of its ability to protect the civilians from coming to harm during the conflict. This principle was given a legal interpretation in Prosecutor $v$ Rutaganda when the Trial Chamber held that a person can also be held liable for an international crime where there is a duty to act and the person omits to act (ICTR 1999: para 41). 


\section{Simon Ben Okolo}

\section{Responsibility of the international community}

President Bill Clinton in reacting to the United States' failure to act in Rwanda stated that 'we did not act quickly enough after the killing began. We should not have allowed the refugee camps to become safe haven for the killers. We did not immediately call these crimes by their rightful name: genocide' (Corey 1998). The question this statement raises, therefore, is whose responsibility is it to declare a situation as genocide? Is it that of the UN Security Council or that of individual powerful states? The Genocide Convention does not create within it a supervisory or monitoring/implementation mechanism with the responsibility of ensuring the prevention and punishment of genocide. However, Article VII of the Convention provides for the parties to the Convention to call upon the competent organs of the UN to take action for the suppression and prevention of such crimes (Convention on the Prevention and Punishment of the Crime of Genocide 1948: art. VIII). From the wordings of Article VIII, it is obvious that the duty of declaring a given situation as genocide is vested in state parties, since their duty is to inform the UN organs to take action in the 'suppression and prevention of acts of genocide...? The reasoning is that the particular state must have reached a conclusion given the set of facts available to it that genocide has occurred. The reference to 'competent organs' of the UN is anticipatory of the fact that the UN Security Council is not the only competent authority to deal with the issue of genocide.

The determination and eventual declaration that acts of genocide have occurred in such a situation is a process of both legal and political decision-making. Meanwhile, while this process of labelling or branding is going on, thousands of lives continue to be lost. It is apposite to mention that while the United States and the world were debating as to the correct labelling of the Darfur situation in 2004, thousands of Darfurians were being killed or forcefully removed from their homes by the Government of Sudan backed Janjaweed militia. The United States was bold enough in 2004 to label the atrocities in Darfur as genocide. ${ }^{17}$ However welcome the labelling was, the expected outcome of such labelling was never seen. The argument about the correct labelling of the atrocities in Darfur

17 See Powell 2004. 
as genocide or crimes against humanity will be of no use to the victims if the international community does not assist them. The victims, most of whom are not literate enough to read and understand the daily news, and even if they can, are far removed from such privileges, cannot definitely understand the legal definitions of genocide and crimes against humanity. What they do know is that civilians are being killed and raped, and that they need help from whichever quarter such help can come from.

The international community's inaction in cases of genocide across the world could be responsible for the modern day genocide that has been witnessed. For instance, in an address to his generals prior to the invasion of Poland, Adolf Hitler asked a rhetorical question, '[W] ho, after all, speaks today of the annihilation of the Armenians?' (Graber 1996:128) Similarly, the inaction by the United Nations and the world at large to stop the Igbo genocide of 1966-1970 and punish the perpetrators has been advocated as the foundational genocide in post-conquest Africa (Ekwe-Ekwe 2007:5). ${ }^{18}$ Ekwe-Ekwe argues that this inaction shows that the world did not learn much from the genocide of the 1940s and that ' $\mathrm{i}] \mathrm{t}$ is precisely because the perpetrators of the Igbo genocide appeared to have been let off the hook for their crimes by the rest of Africa and the wider world, that Africa did not have to wait for long before the politics of the Nigerian genocide-state metamorphosed violently beyond the Nigerian frontiers' (Ekwe-Ekwe 2007:9).

The question of whether the Genocide Convention places a duty upon states to intervene militarily to stop the killings is still elusive and largely unanswered. Raphael Lemkin (1947:150) is of the view that ' [b]y declaring genocide as a crime under international law and by making it a problem of international concern, the right of intervention on behalf of minorities slated for destruction has been established'. The matter of intervention can however be inferred from Article VIII of the Convention especially with regard to the debate over its adoption (Schabas 2000:491). However, with the adoption of the responsibility to protect principle, the obligations are clearly spelt out now. The principle embedded in the responsibility to protect is that 'intervention for human protection purposes,

18 See also Dadrian 1989:221, where the author asserted: 'Indeed, that ignored genocide begets another genocide appears to be a historical fact', and Dadrian 1998:503. 


\section{Simon Ben Okolo}

including military intervention in extreme cases, is supportable when major harm to civilians is occurring or imminently apprehended, and the state in question is unable or unwilling to end the harm, or is itself the perpetrator' (International Commission on Intervention and State Sovereignty 2001: para 2.25). If the spirit of the concept is implemented by the United Nations, the question of whether to intervene in a genocidal situation would have been taken care of. At the judicial level, it is also expected that if states were to implement the provisions of the ICC in their domestic legislations, then genocidaires can always be hunted and prosecuted either domestically or at the ICC.

The language of Article I of the Genocide Convention suggests that a certain kind of action is required on the part of the parties to the convention to prevent and punish crimes of genocide. The use of the word 'undertake' translates to a promise to do something. Observing the principle of pacta sunt servanda (agreements must be kept), ${ }^{19}$ one expects action in a situation of genocide. You do not put into effect the words of the Convention by sitting idle in the face of genocide. The enabling article in the Genocide Convention that allows states to call a situation genocide is Article VIII. This does not however mean that the state is the one responsible for declaring the situation as genocide. The Convention does not stipulate the action that needs to be taken in order to stop the genocide from continuing. It does not also require the UN to mount a Chapter VII ${ }^{20}$ action in order to stop it. While this might be true, literally, the implication of such genocidal actions constituting a threat to international peace and security exists and hence, requires a Chapter VII action. With the introduction of the responsibility to protect into the debate on civilian protection, it becomes obligatory for the international community to act in preventing and punishing those involved in perpetrating the act of genocide.

\section{Conclusion}

Invariably, what the victims of the atrocities in Darfur and elsewhere want is protection from the killings. No reasonable person would prefer that the

19 See Vienna Convention on the Law of Treaties 1969: art. 26.

20 Of the UN Charter. 
authorities punish the perpetrator of a grave injustice rather than prevent such a person from inflicting such harm on the victim in the first place. The logic, therefore, suggests that instead of the international community engaging in academic gymnastics of determining whether the killing fields of Darfur qualify as genocide, crimes against humanity, war crimes or domestic crimes, the international community should strive to prevent further killings even if it later turns out that it made a mistake in its labelling of the situation. As Abbas Bundu, a one time Executive Secretary of ECOWAS ${ }^{21}$ had argued in favour of ECOWAS' intervention in Liberia that he would rather make a mistake trying to solve a problem than to remain completely indifferent (Adisa 1992:211). The question, therefore, is what effect do threats of intervention have on a genocidal state? Does it deter or embolden such a regime set on a genocidal path? The UN Report of the independent inquiry into actions of the UN during the 1994 genocide in Rwanda, while blaming the UN for its failure to act in Rwanda, noted that 'acknowledgment of responsibility must also be accompanied by a will for change: a commitment to ensure that catastrophes such as genocide in Rwanda never occur anywhere in the future' (United Nations 1999:3). Four years from the charge to the UN to be more committed in preventing atrocities of such scale, Darfur caught the international community's attention. Five years after making international headlines, the international community is still at a loss on the best approach to preventing and putting a stop to the continued loss of lives in Darfur (Agbakwa 2005:518). The question that international lawyers and international relations scholars need to address is whether the need to respect Article 2 (4) of the Charter automatically trumps the global duty to prevent genocide (Koh 2002:28). Put blandly, should the international community respect the letters of the law, that is, the so-called rule of non-intervention and use of force, while the spirit of the law - protection of civilians - is consigned to the dustbin?

21 Economic Community of West African States 


\section{Simon Ben Okolo}

\section{Sources}

\section{Books and articles}

Adisa, Jinmi 1992. The politics of regional military cooperation: The case of ECOMOG [ECOWAS Monitoring Group]. In: Vogt, Margaret M. ed. The Liberian crisis and ECOMOG: A bold attempt at regional peacekeeping. Lagos, Gabumo.

Agbakwa, C. Shedrack 2005. Genocidal politics and racialization of intervention: From Rwanda to Darfur and beyond. German Law Journal, 6 (2).

Andropolous, George ed. 1994. Genocide: Conceptual and historical dimensions. Philadelphia, University of Pennsylvania Press.

Bryant, Bunyan 1975. Codification of customary international law in the Genocide Convention. Harvard International Law Journal, 16.

Chorbaijan, Levon 1999. Introduction. In: Chorbaijan, Levon and George Shirinian eds. Studies in Comparative Genocide. London, Palgrave.

Dadrian, V.N. 1989. Genocide as a problem of national and international law: The World War I Armenian case and its contemporary legal ramifications. Yale Journal of International Law, 14.

Dadrian, V.N. 1998. The historical and legal interconnections between the Armenian genocide and the Jewish holocaust: From impunity to retributive justice. Yale Journal of International Law, 23.

Ekwe-Ekwe, Herbert 2007. Biafra revisited. Dakar, African Renaissance.

Fein, Helen 1994. Genocide, terror, life integrity and war crimes: The case for discrimination. In: Andropolous 1994.

Flint, Julie and Alex de Waal 2005. Darfur: A short story of a long war. London and New York, Zed Books.

Graber, G.S. 1996. Caravans to oblivion: The Armenian genocide, 1915. New York. John Wiley and Sons.

Horowitz, L. Irving 1994. Science, modernity and authorized terror: Reconsidering the genocidal state. In: Andropolous 1994.

Koh, Harold Hongju 2002. The spirit of the laws. Harvard International Law Journal, 43.

Lefkow, Leslie 2004. Darfur in flames: Atrocities in western Sudan. Human Rights Watch, 16 (5) (A).

Lemkin, Raphael 1947. Genocide as a crime in international law. American Journal of International Law, 41.

Prunier, Gérard 2005. Darfur: The ambiguous genocide. Ithaca, Cornell University Press.

Schabas, William 2000. Genocide in international law. Cambridge, Cambridge University Press. 
Smith, W. Roger 1994. State power and genocidal intent: On the uses of genocide in the $20^{\text {th }}$ century. In: Andropolous 1994.

Spangeburg, Ray, Kit Moser and Diane Moser 2000. The crime of genocide: Terror against humanity. Berkeley Heights, NJ, Enslow Publishers.

Van der Vyver, Johan D. 1999. Punishment and prosecution of the crime of genocide. Fordham International Law Journal, 23.

\section{Reports}

Corey, Charles W. 1998. Clinton addresses Rwanda genocide survivors. Washington File, Kigali, Rwanda, 25 March 1998. Washington, United States Information Service (USIS).

International Commission on Intervention and State Sovereignty 2001. The responsibility to protect. Ottawa, Canada, International Development Research Centre.

International Military Tribunal, Nuremberg 1946. 1 Trials of the major war criminals before the International Military Tribunal, Nuremberg, 14 Nov 1945 - 1 Oct 1946.

Powell, Collin L. (Secretary of State) 2004. The crisis in Darfur. Written remarks before the Senate Foreign Relations Committee, Washington DC, 9 September 2004. Available from: $<$ http://www.state.gov/secretary/rm/36032.htm> [Accessed 21 September 2007].

Report of the International Commission of Inquiry on Darfur to the United Nations SecretaryGeneral 2004. Sub-title: Pursuant to Security Council Resolution 1564 of September 18 2004. Available from: <http://www.un.org/news/dh/Sudan/com_inq_darfur.pdf> [Accessed 16 February 2007].

United Nations 1999. The UN Report of the independent inquiry into actions of the UN during the 1994 genocide in Rwanda. S/1999/1257, 15 December 1999.

United Nations High Commissioner for Human Rights 2006. Deepening crisis in Darfur, two months after the Darfur Peace Agreement: An assessment. Fourth Periodic Report of the United Nations High Commissioner for Human Rights on the Situation of Sudan. Available from: <http://www.ohchr.org/english/countries/sd/docs/4thOHCHR5nov06. pdf $>$ [Accessed 30 January 2007].

\section{UN Resolutions/Treaties and Conventions}

Convention against torture and other cruel, inhuman or degrading treatment or punishment 1987. G.A. res. 39/46, [annex, 39 U.N. GAOR Supp. (No. 51) at 197, U.N. Doc. A/39/51 (1984)], entered into force 26 June 1987.

Convention on the prevention and punishment of crimes against internationally protected persons including diplomatic agents 1977. 1035 U.N.T.S. 167, 13 I.L.M. 41, entered into force 20 February 1977.

Convention on the prevention and punishment of the crime of genocide 1948, adopted by Resolution 260 (III) A of the UN General Assembly on 9 December 1948, entered into force 12 January 1951. 


\section{Simon Ben Okolo}

G.A. (General Assembly) Resolution 96(1) 1946. The Crime of Genocide. UN GAOR, $1^{\text {st }}$ Sess; Part II (Resolutions), U.N. Doc. A/64/Add.1 (1946).

G.A. (General Assembly) Resolution 2391 1968. Convention on the non-applicability of statutory limitation to war crimes and crimes against humanity. UN GAOR 23rd Sess. Agenda Item 64, UN Doc. A/7342 (1968).

International Criminal Court Statute (Rome Statute) 1998. 2187 U.N.T.S. 90, entered into force 1 July 2002.

Vienna Convention on the Law of Treaties 1969. U.N.T.S. 1155, entered into force on 27 January 1980.

\section{Case Law}

ICTR 1999. Prosecutor v Rutaganda, Case No. ICTR-96-3-T, ICTR Trial Chamber, 6 December.

ICTY 1999a. Prosecutor v Kayishema and Ruzindana, ICTY Trial Chamber, 21 May.

ICTY 1999b. Prosecutor v Jelisi, Case No. IT-95-10, ICTY Trial Chamber, 14 December.

ICTY 2001a. Prosecutor v Jelisi, Case No IT-95-10, ICTY Judgment, 26 February.

ICTY 2001b. Prosecutor v Kayishema and Ruzindana, ICTY Appeal Chamber, 1 June.

ICTY 2001c. Prosecutor v Jelisi, Case No. IT-95-10, ICTY Appeal Chamber, 5 July.

ICTY 2001d. Prosecutor v Krsti, Case No. IT-98-33, ICTY Judgment, 2 August.

ICTY 2003. Prosecutor v Krsti, Case No. IT-98-33, ICTY Appeal Chamber, 19 November.

\section{Media and an interview}

Associated Press 2003. Sudanese President says war against outlaws is Government's priority. 31 December 2003.

Sudan Tribune 2008. Sudan says will fight Darfur rebels even if the whole world screams. Available from: <http://www.sudantribune.com> [Accessed 22 March 2008].

Yusuf, Abubakar 2007. Member of Darfur Coalition. Interviewed by the author, Lusaka, Zambia, 19 July 2007. 